\title{
PEMBUATAN FULL PROTHESA PADA RAHANG NORMAL DAN PADA RAHANG CROSSBITE
}

\author{
Oleh \\ Merry Thressia, Mustam \\ Akademi Teknik Gigi (ATG) Padang.
}

\begin{abstract}
Complete removable dentures or full dentures pothesa is to replace all the original teeth along the gum tissue section is missing, a person who has lost all molars, will be able to inhibit the function of mastication, phonetics function, aesthetic function and affect the psychological state. Crossbite is a disorder that leads to a deterioration of the jaw teeth have a better position on the buccal or lingual tooth appropriate antagonist diarcade up or down.

The design of this study is the study of literature, where the author collects various studies relating to the manufacture keperpustakaan full prothesis in normal jaw and jaw crossbite.

This study aims to determine the process of making a complete removable denture in normal and crossbite jaw. Results of research on the manufacture of full prothesis in normal jaw and the jaw crossbite is through the process of making the same and, where there is a difference in the preparation of the teeth to be adjusted to shape the conditions or circumstances jaw models.
\end{abstract}

Keywords: full dentures pothesa, crossbite

\begin{abstract}
ABSTRAK
Gigi tiruan lengkap lepasan atau full pothesa adalah gigi tiruan untuk menggantikan semua gigi asli beserta bagian jaringan gusi yang hilang, seseorang yang telah kehilangan semua gigi geliginya, akan dapat menghambat fungsi pengunyahan, fungsi fonetik, fungsi estetik dan mempengaruhi keadaan psikis. Crossbite merupakan kelainan pada rahang yang mengakibatkan ketidakteraturan gigi yang memiliki posisi yang lebih bucal atau lingual dari gigi antagonis yang sesuai diarcade atas atau bawah.

Desain penelitian ini bersifat study literature, dimana penulis mengumpulkan bermacam studi keperpustakaan yang berhubungan dengan pembuatan full prothesa pada rahang normal dan pada rahang crossbite.

Penelitian ini bertujuan untuk mengetahui proses pembuatan gigi tiruan lengkap lepasan pada rahang normal dan crossbite. Hasil penelitian mengenai pembuatan full prothesa pada rahang normal dan pada rahang crossbite adalah melalui proses dan pembuatan yang sama, dimana terdapat perbedaan pada penyusunan gigi geligi yang harus disesuaikan dengan bentuk kondisi atau keadaan model rahang.
\end{abstract}

Kata kunci : full pothesa, crossbite

\section{PENDAHULUAN}

Seiring bertambahnya usia, semakin besar kerentanan seseorang untuk kehilangan gigi. Keadaan ini berdampak pada meningkatnya kebutuhan akan gigi tiruan. Gigi mempunyai banyak peran pada seseorang, hilangnya gigi dari mulut seseorang akan mengakibatkan perubahan- 
perubahan anatomis, fisiologis maupun fungsional, bahkan dapat menyebabkan trauma psikologis. Riset Kesehatan Dasar (RISKESDAS) Departemen Kesehatan Republik Indonesia tahun 2007 melaporkan bahwa, kehilangan gigi ditemukan pada kelompok umur 45-54 tahun sebesar 1,8\%, 55-64 tahun sebesar 5,9\%, dan pada kelompok umur 65 tahun ke atas, kehilangan gigi mencapai $17,6 \%$. Pemakaian gigi tiruan diperlukan bila seseorang telah kehilangan giginya.

Gigi tiruan pertama kali dikenal pada tahun 700SM. Pada masa tersebut gigi tiruan masih terbuat dari gading, tulang ikan paus atau tulang kudanil yang diikat dengan semacam kawat yang terbuat dari emas. Teknik ini bertahan selama hampir 2000 tahun. Gigi tiruan yang murah dan nyaman mulai diciptakan tahun 1839 oleh Nelson Goodyear di Amerika Serikat, bahannya berupa karet keras yang disebut vulcanite.

Gigi tiruan akrilik merupakan gigi tiruan yang paling sering dan umum dibuat pada saat ini, baik untuk kehilangan satu atau seluruh gigi. Gigi tiruan ini mudah dipasang dan dilepas oleh pasien. Bahan akrilik merupakan campuran bahan sejenis plastik yang manipulasinya mudah, murah, ringan dan bisa diwarnai sesuai dengan warna gigi dan warna gusi.

Berdasarkan jumlah gigi yang hilang dan diganti dengan gigi palsu (artificial teeth), maka prostodonsia dibagi menjadi dua bagian yaitu : gigi tiruan lengkap (full denture) dan gigi tiruan sebagian (partial denture). Gigi tiruan sebagian (partial denture) dapat dibagi lagi menjadi gigi tiruan sebagian lepasan (removable prosthodontics) dan gigi tiruan sebagian cekat (fixed prosthodontics).

Pemakaian gigi tiruan mempunyai tujuan bukan hanya memperbaiki fungsi pengunyahan, fonetik, dan estetik saja, tetapi juga harus dapat mempertahankan kesehatan jaringan tersisa. Gigi tiruan berujung bebas (distal extension) mempunyai lebih banyak masalah dibandingkan dengan gigi tiruan sebagian lepasan bersandaran ganda (alltooth supported). Klasifikasi Kennedy maupun klasifikasi Soelarko yang berdasarkan topografi daerah tidak bergigi memasukkan daerah tidak bergigi berujung bebas sebagai kelas yang pertama (Kelas-1) (Giffin, 1996; Keng ,1996; Navas dan del Campos, 1993; Boucher dan Renner, 1982; Henderson dan Steffel,1973;).

Sekarang ini banyak ditemukan kelainan-kelainan pada rahang manusia, antara lain Crossbite dan Eksbite. Crossbite adalah ketika gigi atas dan gigi bawah tersusun berlawanan dari susunan normal yang tepat. Jika lengkungan atas dari gigi terlalu sesak atau padat, maka gigi pada rahang atas menjadi tidak sesuai lagi dengan gigi pada rahang bawah. Hal ini dapat menyebabkan masalah ketika makan dan mengunyah karena gigi geligi tidak seharusnya tersusun seperti itu. Hal ini hampir selalu dihubungkan dengan buruknya bentuk dan barisan lengkungan gigi. Lengkungan atas seringnya sempit dan tajam sedangkan lengkungan bawah seringnya lebar dan berlebih.

Lengkungan yang ideal ditunjukkan dengan seluruh permukaan oklusal gigi atas hanya bertemu dengan permukaan oklusal gigi bawah antagonisnya. Pada lengkungan yang sempit satu sisi bisa bergeser manjadi Crossbite yang sekarang bersesuaian dengan bagian dalam gigi bawah. Hal ini bisa terjadi pada satu bagian (unilateral) atau bilateral dimana Crossbite terjadi dikedua sisi. Akibat dari hal ini terutama adalah menonjolkan kepadatan gigi yang ada. Crossbite dapat mempengaruhi posisi mandibula kedalam atau keluar dari jalur pengunyahan. Selama masa pertumbuhan hal ini dapat berjalan tidak simetris.

Berdasarkan masalah di atas, maka penulis akan mempelajari bagaimana cara membuat Full prothesa pada rahang normal dan pada rahang yang Crossbite". Tujuan akhir dari penelitian ini adalah sebagai bahan 
masukan bagi dokter gigi dan teknisi gigi dalam pembuatan Full prothesa.

Manfaat dan target luaran dari penelitian ini adalah (1.) untuk serta sebagai bahan masukan bagi dokter gigi dan teknisi gigi dalam pembuatan Full prothesa, (2.) Dapat menambah wawasan bagi penulis dalam pembuatan Full prothesa (3.) Sebagai bahan informasi bagi mahasiswa diperpustakaan Akademi Teknik Gigi (ATG) Padang, (4.) Luaran dari penelitian ini diharapkan nantinya berupa artikel untuk jurnal nasional yang terakreditasi atau diseminarkan pada forum ilmiah tingkat.

\section{BAHAN DAN METODA}

Data yang digunakan dalam penelitian ini berupa studi literatur yang diperoleh penulis dengan mengumpulkan bahan dari bermacam-macam studi keperpustakaan dan sumber-sumber buku kedokteran gigi yang berhubungan dengan pembuatan Full prothesa pada rahang normal dan pada rahang Crossbite.

\section{HASIL DAN PEMBAHASAN}

Untuk mendesain gigi tiruan lengkap lepasan (full prothesa) pada rahang normal dan pada rahang crossbite adalah sama, yakni dengan (1) membuat lekuk pengontrol pada dasar model kerja, (2) membuat kawat penguat, (3) membuat garis tengah pada model kerja pada rahang atas dan rahang bawah, dan (4) menarik puncak linggir dari puncak linggir rahang atas dan rahang bawah.
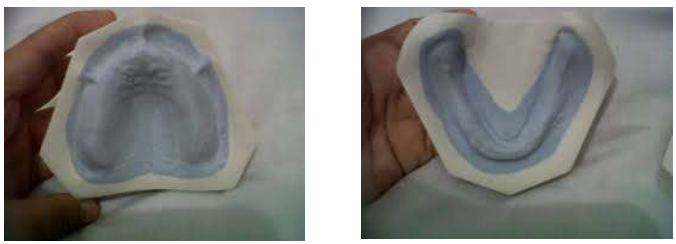

Gambar 1. Desain Full prothesa Rahang Atas dan Rahang Bawah

Untuk menentukan dimensi vertikal dan oklusi sentrik pada rahang normal dan rahang Crossbite adalah (1) membuat landasan Bite plat, (2) membuat tanggul Wax, (3) membuat tanggul gigitan, dan (4) menguji coba tanggul gigitan rahang atas dan rahang bawah, (5) penerapan rumus dimensi vertikal, (6) penentuan gigitan sentrik atau oklusi sentrik, (7) menentukan garis -garis orientasi, dan (8) pemasangan model dalam articulator.

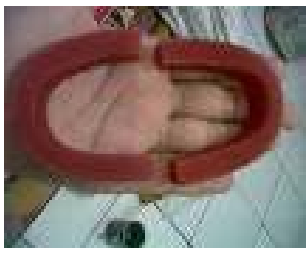

a

Gambar 2.a. Tanggul Wax dengan lempeng Wax yang di lunakkan

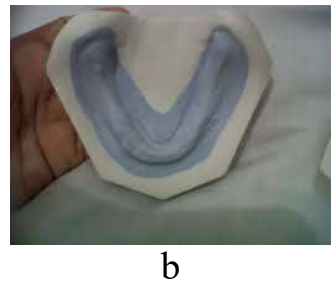

Gambar 2.b. Uji coba tanggul gigitan rahang atas dan rahang bawah
Untuk menyusun gigi geligi pada rahang normal dilakukan secara bertahap yaitu penyusunan gigi anterior atas, gigi anterior bawah, gigi posterior atas, gigi M-1 bawah dan gigi posterior. Untuk penyusunan gigi geligi rahang Crossbite, adalah (1) antar sisa hubungan maxilo-rahang bawah hubungan model mounth menunjukan puncak punggung bukit mandibulasis menentang rahang atas sisa ridge. Ketika menganalisis model edentulous mount, kita harus menentukan jika skema oklusal cross gigitan ditunjukan, (2) menggunakan penguasa Blue Line (Ivolar Vivadent; www.ivoclarvivadent. us) menganalisis sudut ridge sisi hubungan. Setiap kali antar sisa kecendrungan hubungan kurang dari $80^{\circ}$ terhadap bidang horizontal, hubungan lintas gigitan ada. Disini, tepi inferior dari Blue Line penguasa ditempatkan di puncak dari rahang bawah residual ridge. Tepi superior Blue Line penggaris pada $80^{\circ}$ tidak menyentuh puncak punggungan bukal rahang atas. Jadi, sudutnya kurang dari $80^{\circ}$, (3) setelah gigi rahang bawah diatur dan mengatur hubungan lintas gigitan menjadi jelas dan lebih mudah divisualisasikan. Jika pasien posterior kanan maxilla (kiri saat anda melihat set-up) dibawa keluar ke bukal ke skema oklusal yang normal, mak kekuatan oklusal akan menyebabkan langit- langit untuk flex dan menciptakan palatal patah tulangpada resin acrylic, (4) posisi 1 pramolar 
secara normal hubungan oklusal (5) memulai oklusi lintasan gigitan, dimulai dengan transisi gigi. Dalam hal ini premolar kedua atau bicuspid. Very sedikit bulat dari katup bucal dari bicuspid kedua rahang atas. Setelah menepatkan rahang atas bicuspid, menggiling dalam fosa sebuah bucal dan lingual katub dari rahang bawah kedua pra molar sehingga hasilnya adalah oklusi yang berfungsi dan mengarah kekuatan dengan benar, (6) pada situasi oklusi lintas gigitan di molar daerah, harus diperhatikan bahwa mesio- bucal cusp molar 1 rahang atas mengambil alih fungsi dari cusp mesio palatal, (7) Maxsila cusp mesio bucal molar 1 harus melibatkan pemerintah pusat fosa molar 1 rahang bawah, (8) mengatur katub mesio bucal, karena meraka transisi menjadi gigitan lintas grinding mereka turun sedemikian cara bahwa fungsi gerinda dibuat. Jika ada cukup ruang posterior distal molar 1 untuk memungkinkan molar rahang atas ke dua yang di tempatkan, yang kedua molar ditempatkan sehingga katup mesio bucal yang menghungi fosa pusat dari molar kedua rahang bawah.

Tahap berikutnya adalah wax conturing atau waxing adalah membentuk dasar dari gigi tiruan malam sedemikian rupa sehingga dapat menyeimbangkan dengan anatomis gusi dan jaringan lunak mulut.

Flasking merupakan proses penanaman model pada cuvet dengan menggunakan gips kemudian dilakukan packing, yakni proses pencampuran monomer dan polimer resinakrilik atau pengisian akrilik pada mol space pencampuran bahan monomer polimer tergantung hot curing apa yang digunakan yang mempunyai ratio curing dari pabrik. Setelah bahan hut curing diaduk, masukan dan letakan kedalam mol space pada bagian sekitar gigi dengan cara menekankan dengan jari dan batasi dengan plastik basah dan kedua bagian flask tersebut dipress perlahan, kemudian press dibuka dan rapikan sisa - sisa bahan hot curing yang berlebih (lakukan untuk rahang atas dan bawah) dan lakukan pengepresan terakhir dan lakukan proses curing (dimasak).
Deflasking adalah membuka atau melepaskan gigi tiruan dari cuvet dan mol space dengan cara membuka gips yang mengeras dari cuvet, gergaji dan patahkan dinding stone dan dilanjutkan dengan reparasi, yakni suatu tindakan perbaikan atau pembetulan dari gigi tiruan dengan tujuan memperbaiki kelainan, kerusakan, kecekatan, retensi dan stabilisasi. Sebelum melakukan reparasi perlu diadakannya pemeriksaan terlebih dahulu terhadap gigi tiruan yang akan diperbaiki, mencari sebab-sebabnya, sehingga dapat menentukan bagian mana yang akan di reparasi dan langkah awal yang akan di kerjakan. Proses akhir yakni pemolesan, adalah penghalusan dan pengkilapan gigi tiruan tanpa mengubah konturnya, sehingga gigi tiruan Full prothesa mendapatkan hasil yang maksimal.
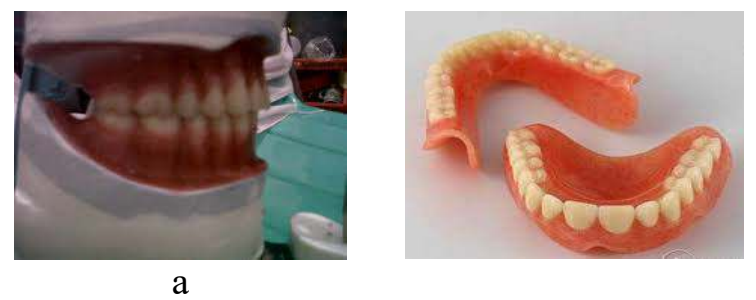

Gambar 3.a. Proses wax conturing

\section{Gambar 3.b. Hasil akhir setelah reparasi dan pemolesan}

\section{KESIMPULAN}

Dari penelitian yang telah dilakukan dapat disimpulkan bahwa proses pembuatan full prothesa pada rahang normal sama dengan pembuatan full prothesa pada rahang crossbite, begitu juga dengan bahan dan alat yang digunakan. Perbedaannya terdapat dalam penyusunan gigi geligi, karena pada rahang normal gigi dapat disusun sesuai dengan cara penyusunan gigi geligi yang sebenarnya yang telah ditetapkan yang sesuai dengan lengkung bitetimenya akan tetapi pada rahang crossbite, kita harus bisa menyesuaikan dengan keadaan rahang yang tidak beraturan dan proses penyusunannya memerlukan waktu yang cukup lama di 
bandingkan penyusunan gigi pada rahang normal.

Tabel 1. Perbandingan penyusunan gigi pada full prothesa rahang normal dan rahang crossbite.

\begin{tabular}{|c|c|}
\hline $\begin{array}{l}\text { Penyusunan Gigi } \\
\text { Rahang Normal }\end{array}$ & $\begin{array}{l}\text { Penyusunan Gigi } \\
\text { Rahang Crossbite }\end{array}$ \\
\hline $\begin{array}{l}\text { RAHANG ATAS } \\
\text { a. Incisivus 1 } \\
\text { - Sumbu miring } 5^{\circ} \\
\text { terhadap garis } \\
\text { midline } \\
\text { - Titik kontak sebelah } \\
\text { mesial tepat pada } \\
\text { garis midline } \\
\text { - Permukaan labial } \\
\text { sesuai dengan } \\
\text { lengkung betirime } \\
\\
\text { b. Incisivus 2 } \\
\text { - Sumbu lebih miring } \\
\text { dari incisivus } 1 \\
\text { - Titik kontak mesial } \\
\text { berkontak dengan } \\
\text { titik kontak distal } \\
\text { incisivus 1 } \\
\text { - Permukaan labial } \\
\text { sesuai degan } \\
\text { lengkung betitrime } \\
\text { c. Caninus } \\
\text { - Sumbu hamper } \\
\text { sejajar dengan garis } \\
\text { midline } \\
\text { - Titik kontak mesial } \\
\text { berkontak dengan } \\
\text { titik kontak distal } \\
\text { incisivus } 2 \\
\text { - Permukaan labial } \\
\text { disesuaikan dengan } \\
\text { lengkung biterime } \\
\text { d. Premolar 1 } \\
\text { - Sumbu tegak lurus } \\
\text { dengan bidak } \\
\text { oklusal } \\
\text { - Titik kontak mesial } \\
\text { berkontak dengan } \\
\text { titik kontak distal } \\
\text { gigi caninus }\end{array}$ & $\begin{array}{l}\text { a.Posisi gigi anterior } \\
\text { harus dengan } \\
\text { posisi over jet } \\
\text { b. Posisi gigi } \\
\text { posterior harus } \\
\text { interlock } \\
\text { c.Memenuhi syarat } \\
\text { curve fomsfi dan } \\
\text { curve moonson } \\
\text { d. Memenuhi } \\
\text { syarat balancing } \\
\text { side dan working } \\
\text { side }\end{array}$ \\
\hline
\end{tabular}

- Permukaan bucal sesuai dengan lengkung biterime

e. Premolar 2

- Sumbu gigi tegak lurus dengan bidak oklusal

- Titik kontak mesial berkontak dengan titik kontak distal premolar 1

- Permukaan bucal sesuai dengan lengkung biterime

f. Molar 1

- Sumbu gigi pada bagian cervical sedikit miring kearah mesial

- Titik kontak mesial berkontak dengan titik kontak distal premolar 2

g. Molar 2

- Sumbu gigi pada bagian cervical lebih miring dari gigi molar 1

- Titik kontak mesial berkontak dengan titik kontak distal molar 1

- Permukaan bucal segaris dengan permukaan molar 1

RAHANG BAWAH

a. Incisivus 1

- sejajar dengan garis vertical

b. Incisivus 2

- sejajar dengan garis vertical

c. Caninus

- membentuk sudut $15^{\circ}$ dari bidang vertical

d. Premolar 1

- tegak lurus dan berada lebih 


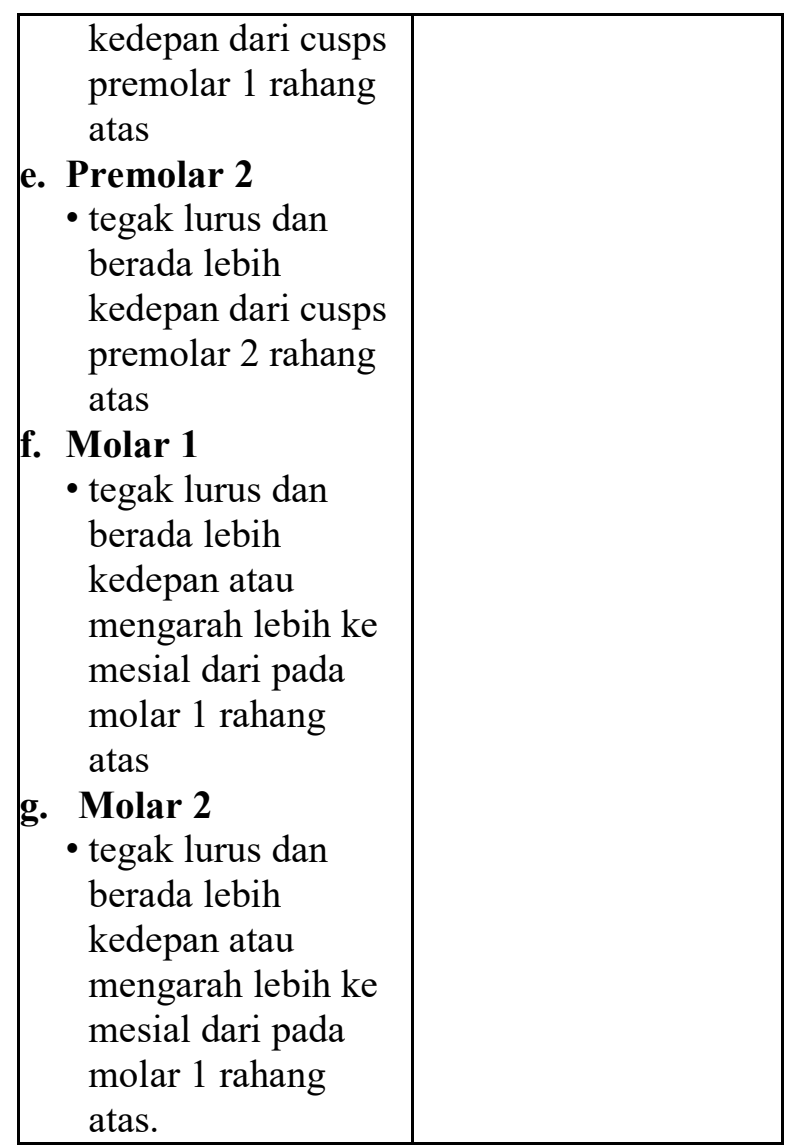

Untuk penelitian berikutnya disarankan agar (1.) pada pembuatan full prothesa harus memperhatikan keutamaan dalam mencetak rahang, karena hasil cetak sangat berpengaruh pada hasil pembuatan full prothesa, (2) pada penentuan dimensi vertical dan oklusi sentry harus betul-betul akurat, karena gigitan pada rahang atas dan rahang bawah harus tepat agar pada penyusunan gigi geligi sesuai pada linggir dan garis mediannya, (3) dalam pembuatan gigi tiruan harus mengetahui bahan yang baik digunakan dalam pembuatan prothesa gigi, terutama pembuatan full prothesa.

\section{DAFTAR PUSTAKA}

Academy of Prosthodontics, 1999, The Glossary of Prosthodontic Terms, Edition 7, Mosby Inc, Universitas Michigan

Utari, Rita I. dkk.1994. Desain dan Teknik Mencetak Pada Pembuatan Geligi Tiruan Lengkap. Jakarta: Hipokrates
Itjing ningsih. 1996. Gigi Tiruan Lengkap Lepasan. Jakarta: EGC. 